\title{
DESIGN, FACILE SYNTHESIS, AND BIOLOGICAL EVALUATION OF NOVEL 1,3-THIAZINE DERIVATIVES AS POTENTIAL ANTICONVULSANT AGENTS
}

\author{
RAVINDAR B ${ }^{1 *}$, SRINIVASA MURTHY M $^{2}$, AFZAL BASHA SHAIK ${ }^{3}$ \\ ${ }^{1}$ Department of Pharmaceutical Chemistry, Centre for Pharmaceutical Sciences, IST, Jawaharlal Nehru Technological University, \\ Kukatpally, Hyderabad, Telangana, India. ${ }^{2}$ Department of Pharmaceutical Chemistry, Vignan Institute of Pharmaceutical Sciences, \\ Near Ramoji Film City, Deshmukhi, Nalgonda, Telangana, India. ${ }^{3}$ Department of Pharmaceutical Chemistry, Vignan Pharmacy Colleges, \\ Vadlamudi, Guntur, Andhra Pradesh, India. Email: ravindarpharma@gmail.com
}

Received: 24 June 2016, Revised and Accepted: 12 July 2016

\section{ABSTRACT}

Objective: Chalcones and their heterocyclic analogs represent an important class of small molecules having anticonvulsant activities. Therefore, in this study, the synthesis and anticonvulsant activity of some new chalcones and 1,3-thiazines were described.

Methods: The reaction of 1-acetylnaphthalene with substituted aromatic aldehydes in the presence of aq. $\mathrm{NaOH}$ afforded corresponding chalcones which upon further cyclization with thiourea resulted in 1,3-thiazine derivatives. The newly synthesized compounds were tested for anticonvulsant activity by pentylenetetrazole-induced seizures method using diazepam as standard

Results: Most of the compounds showed good anticonvulsant activity but is less than diazepam. 1,3-thiazines were more potent than chalcones and among them, compound P4 containing 4-fluorophenyl substituents on the thiazine moiety was more potent as it has prolonged the onset of convulsions by 155.2 seconds.

Conclusion: We described the synthesis and anticonvulsant activity of novel chalcones and 1,3-thiazine derivatives. 1,3-thiazines are more active anticonvulsant agents than chalcones and in particular compounds with electron withdrawing substituents.

Keywords: Chalcone, 1,3-thiazine, Pentylenetetrazole.

(C) 2016 The Authors. Published by Innovare Academic Sciences Pvt Ltd. This is an open access article under the CC BY license (http://creativecommons. org/licenses/by/4. 0/) DOI: http://dx.doi.org/10.22159/ajpcr.2016.v9i5.13676

\section{INTRODUCTION}

Thiazines are a class of six-membered heterocyclic organic compounds with one nitrogen and sulfur atoms situated either in a 1,2-1,31,4- positions or as a part of phenothiazine ring structure (Fig. 1). Due to nitrogen thiazines are chemically basic, 1,3-thiazines are of great importance because they form part of the framework of cephalosporins (3,6-dihydro-2H-1,3-thiazine) [1] and also in some other medicinally important compounds such as xylazine (agonist at the $\alpha_{2}$-adrenergic receptor is used for sedation, anesthesia, muscle relaxation, and analgesia in animals) [2] and chlormezanone (used as an anxiolytic and a muscle relaxant) [3].

They exhibit sundry of pharmacological activities including antimicrobial [4-11], anti-inflammatory [12-15], anticancer [16,17] antidiabetic [18], analgesic [19], immunotropic [20], antitubercular [21], anticonvulsant, and antianxiety [22]. Chalcones, on the other hand, are $\alpha, \beta$-unsaturated enones with a broad range of biological activities and also acts as key synthon in the chemical synthesis of heterocyclic compounds [23]. One important pharmacological activity of chalcones is anticonvulsant property [24]. Most of the anticonvulsant agents in therapy comprise a hydrophobic group with urea or urea like functionality (Fig. 2). Hydrophobicity assists the molecule to reach the brain by crossing blood brain barrier and also to interact with the target site via the hydrophobic interactions whereas the urea or urea like functionality for the polar interactions. These structural features of the existing drugs have become the rationale for designing novel anticonvulsant agent-containing hydrophobic naphthyl and phenyl portions along with polar enone and thiourea moieties in chalcones and 1,3-thiazines, respectively.

In the present work, we reported the synthesis of novel hydrophobic chalcones and 1,3-thiazine derivatives containing electron withdrawing and electron-releasing substituents on the phenyl ring and without any modification on the naphthyl portion to study the effect of such substitutions on anticonvulsant activity.

\section{METHODS}

\section{General}

Melting points were determined in an open capillary melting point apparatus and are uncorrected. ${ }^{1} \mathrm{H}$ NMR was recorded in $\mathrm{CDCl}_{3}$ on Bruker WM $400 \mathrm{MHz}$ spectrometer with TMS as internal standard. Infrared spectra were recorded ( $\mathrm{KBr}$ ) on Perkin-Elmer AC-1 spectrophotometer Microanalyses were performed on Carloerba EA-1108 element analyzer and were within $\pm 0.4 \%$ of the theoretical values. Reaction completion was monitored by Thin-layer chromatography (TLC) using Silica gel-G for TLC (Merck). All the compounds have been purified by column chromatography performed on Silica gel (100-200 mesh, Merck), ethyl acetate, and hexane as solvent systems by gradient elution. Diazepam was obtained from and pentylenetetrazole (PTZ) was purchased from Sigma and was dissolved in normal saline. The healthy Albino rats (Wistar, 100-150 g, 5-6 weeks) were obtained from Mahaveer enterprises, Kolkata.

\section{Chemistry}

General procedure for the synthesis of chalcones (A1-A6) and 1,3-thiazines (P1-P6)

To a mixture of 1-acetylnaphthalene (A) $(1.94 \mathrm{~g}, 0.01 \mathrm{~mol})$ and various substituted aromatic aldehydes ( $0.01 \mathrm{~mol}$ ) (Fig. 3) in ethanol $(50 \mathrm{~mL})$ cooled to $5-10^{\circ} \mathrm{C}$, aqueous sodium hydroxide $(70 \%, 5 \mathrm{~mL})$ was added dropwise with constant stirring. The reaction mixture was further stirred for 2 hrs and left overnight and neutralized with concentrated hydrochloric acid to form a solid which was collected and crystallized from a suitable solvent to get chalcones (A1-A6). To a solution of chalcones $(0.01 \mathrm{~mol})$ and thiourea $(0.01 \mathrm{~mol})$, ethanolic $\mathrm{KOH}$ was added and refluxed for $5 \mathrm{hrs}$ (Scheme 1). The 
reaction mixture was poured into ice-cold water, the solid product obtained was filtered, washed with water and crystallized from a suitable solvent to gain 1,3-thiazines (P1-P6). The purity of all the compounds was established by TLC using a mixture of hexane and ethyl acetate as a mobile phase. All the compounds are purified by column chromatography.

(E)-1-(napthalen-5-yl)-3-phenylprop-2-en-1-one (A1) yellowish solid; Yield: 81\%; m.p. $151-154^{\circ} \mathrm{C}$; infrared (IR) $\left(\mathrm{KBr}, \mathrm{cm}^{-1}\right)$ : 1669.24 (-CO-) $1518.12\left(-\mathrm{CH}=\mathrm{CH}-\right.$ ), 3047.79 (Ar-CH strecthing); ${ }^{1} \mathrm{H}$ NMR $(400 \mathrm{MHz}$ $\left.\mathrm{CDCl}_{3}, \mathrm{ppm}\right)$ : 7.56-7.60 (1H,d, J=16, $\left.\mathrm{Ar}-\mathrm{CH}=\right), 7.90-7.92(1 \mathrm{H}, \mathrm{d}, \mathrm{J}=8.8,-\mathrm{CO}-$ $\mathrm{CH}=\mathrm{C}-$ ), 7.42-7.88 (m, C-2', 3', 4', 5', 6', 7', Ar-H), 9.19 (1H,d, C-8', Ar-H)

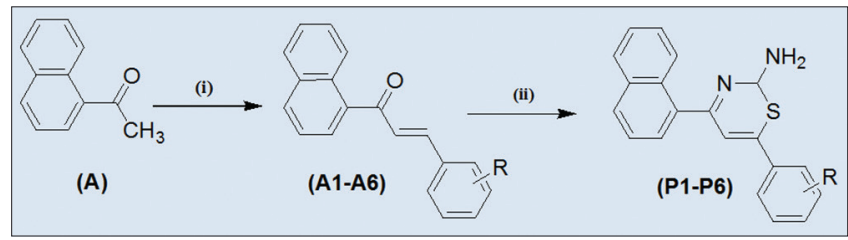

Scheme 1: Synthesis of chalcones (A1-A6) and 1,3-thiazines (P1-P6); (i) substituted aromatic aldehydes, ethanol, aq. $\mathrm{NaOH}$; (ii) Thiorea, ethanolic KOH<smiles>C1=CNSC=C1</smiles>

$2 \mathrm{H}$-1,2-thiazine

3,4-dihydro-2H-1,3-thiazine<smiles>C1=CSC=CN1</smiles>

4H-1,4-thiazine
$7.14(1 \mathrm{H}, \mathrm{t}, \mathrm{C}-4$ ", $\mathrm{Ar}-\mathrm{H})$; Anal. Calcd for: $\mathrm{C}_{19} \mathrm{H}_{14} \mathrm{O}: \mathrm{C}, 47.96 ; \mathrm{H}, 2.59$; Found: C, $48.01 ; \mathrm{H}, 2.61$.

(E)-3-(4-methylphenyl)-1-napthalen-5-yl)prop-2-en-1-one (A2) yellowish solid; Yield: 53\%; m.p. $175-177^{\circ} \mathrm{C}$; IR $\left(\mathrm{KBr}, \mathrm{cm}^{-1}\right)$ : 1669.24 (-CO-), 1515.66 (- $\mathrm{CH}=\mathrm{CH}-$ ), 2921.36 (Ar-CH strecthing); ${ }^{1} \mathrm{H}$ NMR (400 MHz, $\left.\mathrm{CDCl}_{3}, \mathrm{ppm}\right): 2.35\left(3 \mathrm{H}, \mathrm{s}, \mathrm{CH}_{3}\right), 7.58-7.62(1 \mathrm{H}, \mathrm{d}, \mathrm{J}=16, \mathrm{Ar}-$ $\mathrm{CH}=), 7.92-7.94(1 \mathrm{H}, \mathrm{d}, \mathrm{J}=8.8,-\mathrm{CO}-\mathrm{CH}=\mathrm{C}-), 7.40-7.84\left(\mathrm{~m}, \mathrm{C}-2^{\prime}, 3^{\prime}, 4^{\prime}, 5^{\prime}, 6^{\prime}\right.$, 7', Ar-H), 9.14 (1H,d, C-8', Ar-H), 7.16-7.26 (m, C- 2", 3", 5", 6", Ar-H); Anal. Calcd for: $\mathrm{C}_{20} \mathrm{H}_{16} \mathrm{O}$ : C, 52.04; H, 3.49; Found: C, 52.09; H, 3.50.

(E)-3-(4-chlorophenyl)-1-napthalen-5-yl)prop-2-en-1-one (A3) yellowish solid; Yield: 59\%; m.p. $189-192^{\circ} \mathrm{C}$; IR $\left(\mathrm{KBr}, \mathrm{cm}^{-1}\right)$ : 1667.95 (-CO-), 1520 (-CH=CH-), 2920.30 (Ar-CH strecthing), 1064.38 (C-Cl); ${ }^{1} \mathrm{H}$ NMR $\left(400 \mathrm{MHz}, \mathrm{CDCl}_{3}, \mathrm{ppm}\right):$ 7.56-7.60 $(1 \mathrm{H}, \mathrm{d}, \mathrm{J}=16, \mathrm{Ar}-\mathrm{CH}=), 7.90-$ $7.92(1 \mathrm{H}, \mathrm{d}, \mathrm{J}=8.8,-\mathrm{CO}-\mathrm{CH}=\mathrm{C}-), 7.42-7.88\left(\mathrm{~m}, \mathrm{C}-2^{\prime}, 3^{\prime}, 4^{\prime}, 5^{\prime}, 6^{\prime}, 7^{\prime}, \mathrm{Ar}-\mathrm{H}\right)$, 9.25 (1H,d, C- 8', Ar-H), 7.22-7.24 (m, C- 2", 3", 5", 6", Ar-H); Anal. Calcd for: $\mathrm{C}_{19} \mathrm{H}_{13}$ OCl: C, 53.50; H, 4.21; Found: C, 53.52; H, 4.24 .

(E)-3-(4-fluorophenyl)-1-napthalen-5-yl)prop-2-en-1-one (A4) fluorescent yellowish solid; Yield: $70 \%$; m.p. $167-169^{\circ} \mathrm{C}$; IR $(\mathrm{KBr}$, $\mathrm{cm}^{-1}$ ): 1663.12 (-CO-), 1518.51 (-CH=CH-), 3030.66 (Ar-CH strecthing), 1047.70 (C-F); ${ }^{1} \mathrm{H}$ NMR $\left(400 \mathrm{MHz}, \mathrm{CDCl}_{3}, \mathrm{ppm}\right): 7.52-7.58(1 \mathrm{H}, \mathrm{d}, \mathrm{J}=16$, $\mathrm{Ar}-\mathrm{CH}=$ ), 7.94-7.96 (1H,d, J=8.8, -CO-CH=C-), 7.46-7.92 (m, C-2', 3', 4', 5', 6', 7', Ar-H), 9.09 (1H,d, C- 8', Ar-H), 6.92-7.28 (m, C- 2", 3", 5", 6", Ar-H); Anal. Calcd for: $\mathrm{C}_{19} \mathrm{H}_{13}$ OF: C, 43.67; H, 2.09; Found: C, 43.69; H, 2.11.

(E)-3-(4-dimethylaminophenyl)-1-napthalen-5-yl)prop-2-en-1-one (A5) yellowish solid; Yield: 91\%; m.p. $231-233^{\circ} \mathrm{C}$; IR $\left(\mathrm{KBr}, \mathrm{cm}^{-1}\right)$ : 1660.35 (-CO-), 1513.33 (-CH=CH-), 1020-1250 (aliphatic amines C-N), 2922.91 (Ar-CH stretching); ${ }^{1} \mathrm{H}$ NMR $\left(400 \mathrm{MHz}, \mathrm{CDCl}_{3}, \mathrm{ppm}\right): 2.85$ (6H, s, Ar-N $\left.\left(\mathrm{CH}_{3}\right)_{2}\right), 7.60-7.64(1 \mathrm{H}, \mathrm{d}, \mathrm{J}=16, \mathrm{Ar}-\mathrm{CH}=), 7.94-7.96(1 \mathrm{H}, \mathrm{d}, \mathrm{J}=8.8,-\mathrm{CO}-$ $\mathrm{CH}=\mathrm{C}-$ ), 7.40-7.86 (m, C-2', 3', 4', 5', 6', 7', Ar-H), 9.23 (1H,d, C- 8', Ar-H), 6.56-7.14 (m, C- 2", 3", 5", 6", Ar-H); Anal. Calcd for: $\mathrm{C}_{21} \mathrm{H}_{19} \mathrm{ON}$ : C, 63.48; H, 3.39; N, 10.09; Found: C, 63.52; H, 3.41; N, 10.10.

(E)-3-(4-hydroxyphenyl)-1-napthalen-5-yl)prop-2-en-1-one (A6) Yield: Yellowish solid; 69\%; m.p. 194-196º $\mathrm{C}$; IR $\left(\mathrm{KBr}, \mathrm{cm}^{-1}\right)$ : 1663.99 (-CO-), 1515.76 (-CH=CH-), 3047.79 (Ar-CH strecthing), 3443.23 (hydroxy benzene); ${ }^{1} \mathrm{H}$ NMR $\left(400 \mathrm{MHz}, \mathrm{CDCl}_{3}, \mathrm{ppm}\right): 5.1(1 \mathrm{H}, \mathrm{s}, 4$ " $-\mathrm{OH})$, 7.56-7.60 (1H,d, J=16, Ar-CH=), 7.90-7.92 (1H,d, J=8.8, -CO-CH=C-), 7.42-7.88 (m, C-2', 3', 4', 5', 6', 7', Ar-H), 9.19 (1H,d, C- 8', Ar-H), 6.68-7.13 (m, C- 2", 3", 5", 6", Ar-H); Anal. Calcd for: $\mathrm{C}_{19} \mathrm{H}_{14} \mathrm{O}_{2}$ : C, 54.56; H, 3.66; Found: C, 54.59; H, 3.69.

Fig. 1: Structures of different types of thiazines

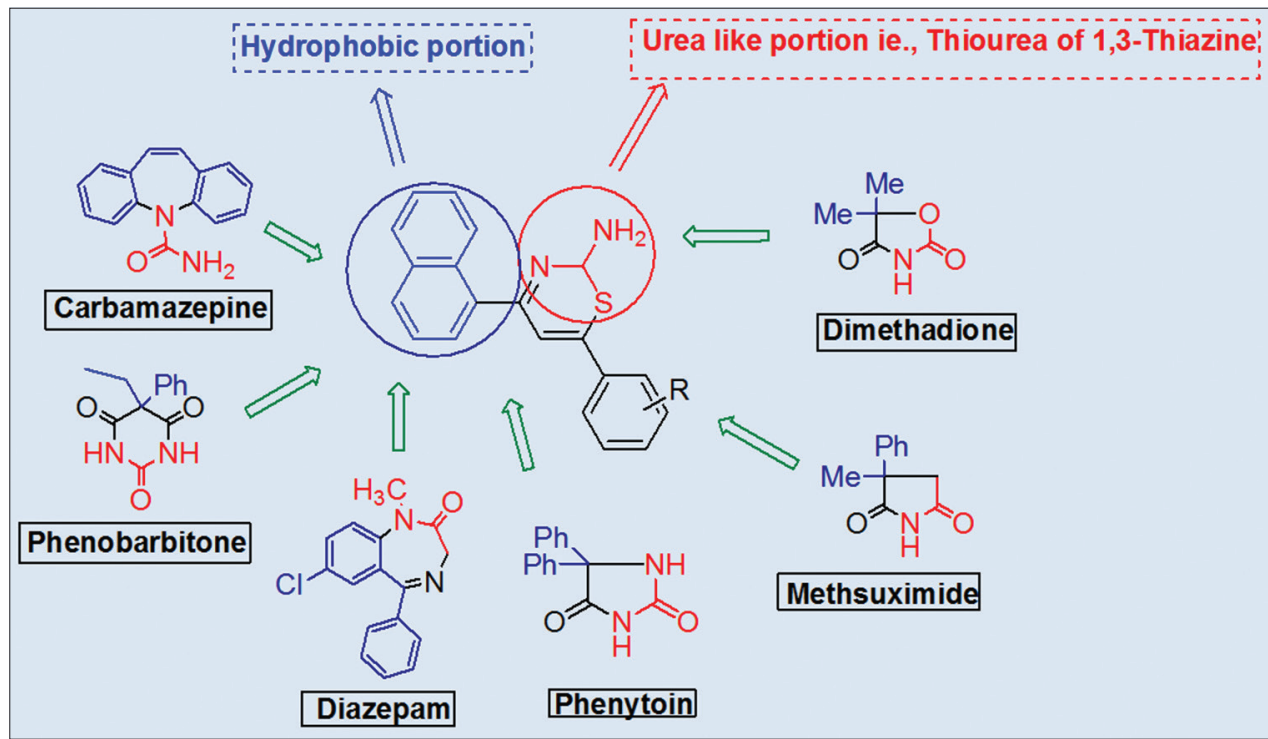

Fig. 2: Design of hydrophobic group linked 1,3-thiazine analouges for their anticonvulsant activity hydrophobic portion shown in blue where as polar urea or urea like portion in red 
4-(napthalen-5-yl)-6-phenyl-2H-1,3-thiazin-2-amine (P1) Yield: Pale yellowish solid: $69 \%$; m.p. $194-196^{\circ} \mathrm{C}$; IR $\left(\mathrm{KBr}, \mathrm{cm}^{-1}\right): 3341.52\left(\mathrm{NH}_{2}\right)$ 1621.35 (C=N), 688 (C-S),1564 (C=C), 2921.38 (Ar-CH stretching); ${ }^{1} \mathrm{H}$ NMR (400 MHz, CDCl 3 , ppm): $4.61\left(2 \mathrm{H}, \mathrm{s},-\mathrm{NH}_{2}\right), 7.01(1 \mathrm{H}, \mathrm{s}, \mathrm{C}-6, \mathrm{Ar}-\mathrm{H})$ $7.22(1 \mathrm{H}, \mathrm{s}, \mathrm{Ar}-\mathrm{H}), 7.32$ (4H, m,C-3',5',6",7”, Ar-H), 7.38-7.67 (6H, m, C-2',2",3",4",5",7", Ar-H); Anal. Calcd for: $\mathrm{C}_{19} \mathrm{H}_{14} \mathrm{O}_{2}: \mathrm{C}, 75.92 ; \mathrm{H}, 5.10$; 8.85; Found: C, 76.12; H, 5.19; N, 8.97.

4-(napthalen-5-yl)-6-p-tolyl-2H-1,3-thiazin-2-amine (P2) off-white solid; Yield: $96 \%$; m.p. $149-151^{\circ} \mathrm{C}$; IR $\left(\mathrm{KBr}, \mathrm{cm}^{-1}\right): 3385.56\left(\mathrm{NH}_{2}\right)$ $1633.23(\mathrm{C}=\mathrm{N}), 683(\mathrm{C}-\mathrm{S}), 1528.98(\mathrm{C}=\mathrm{C}), 3068.52$ (Ar-CH stretching); ${ }^{1} \mathrm{H}$ NMR $\left(400 \mathrm{MHz}, \mathrm{CDCl}_{3}, \mathrm{ppm}\right): 5.11\left(2 \mathrm{H}, \mathrm{s},-\mathrm{NH}_{2}\right), 6.95(1 \mathrm{H}, \mathrm{s}, \mathrm{C}-6$ Ar-H), 2.35 (3H, s, ' $\left.\mathrm{CH}_{3}\right), 7.12\left(2 \mathrm{H}, \mathrm{d}, \mathrm{J}=7 \mathrm{~Hz}, \mathrm{C}-3^{\prime}, 5^{\prime} \mathrm{Ar}-\mathrm{H}\right), 7.30(2 \mathrm{H}, \mathrm{d}$ J=7Hz,C-2',6' Ar-H), 7.32-7.67 (7H,m, C-2",3",4",5",6",7",8" Ar-H); Anal. Calcd for: $\mathrm{C}_{21} \mathrm{H}_{18} \mathrm{~N}_{2} \mathrm{~S}$ : C, 76.33; H, 5.49; N, 8.48; Found: C, 76.44; H, 5.57; N, 9.05 .

6-(4-chlorophenyl)4-(napthalen-5-yl)-2H-1,3-thiazin-2-amine (P3) pale yellowish solid; Yield: 65\%; m.p. $178-179^{\circ} \mathrm{C}$; IR $\left(\mathrm{KBr}, \mathrm{cm}^{-1}\right)$ : $3412.97\left(\mathrm{NH}_{2}\right), 1619.15(\mathrm{C}=\mathrm{N}), 691(\mathrm{C}-\mathrm{S}), 1584.04(\mathrm{C}=\mathrm{C}), 2952.91$ (Ar-CH stretching) 804.05 (C-Cl); ${ }^{1} \mathrm{H}$ NMR $\left(400 \mathrm{MHz}, \mathrm{CDCl}_{3}, \mathrm{ppm}\right)$ $5.60\left(2 \mathrm{H}, \mathrm{s},-\mathrm{NH}_{2}\right), 7.18(1 \mathrm{H}, \mathrm{s}, \mathrm{C}-6 \mathrm{Ar}-\mathrm{H}), 7.01\left(2 \mathrm{H}, \mathrm{d}, \mathrm{J}=7 \mathrm{~Hz}, \mathrm{C}-3^{\prime}, 5^{\prime} \mathrm{Ar}-\mathrm{H}\right)$ 7.42 (2H,d, J=7Hz,C-2',6' Ar-H), 7.46-7.84 (7H, m, C-2",3",4",5",6",7",8" Ar-H); Anal. Calcd for: $\mathrm{C}_{20} \mathrm{H}_{15} \mathrm{ClN}_{2} \mathrm{~S}: \mathrm{C}, 68.46 ; \mathrm{H}, 4.31 ; \mathrm{N}, 10.10$; Found: C, $68.55 ; \mathrm{H}, 4.40 ; \mathrm{N}, 10.19$.

6-(4-fluorophenyl)4-(napthalen-5-yl)-2H-1,3-thiazin-2-amine (P4) pale yellowish solid; Yield: $68 \%$; m.p. $188-190^{\circ} \mathrm{C}$; IR $\left(\mathrm{KBr}, \mathrm{cm}^{-1}\right)$ : $3424.68\left(\mathrm{NH}_{2}\right), 1608.69$ (C=N), $711(\mathrm{C}-\mathrm{S}), 1573.85$ (C=C), 3046.70 (Ar-CH stretching), 930.36 (C-F); ${ }^{1} \mathrm{H}$ NMR $\left(400 \mathrm{MHz}, \mathrm{CDCl}_{3}, \mathrm{ppm}\right)$ : $5.72\left(2 \mathrm{H}, \mathrm{s},-\mathrm{NH}_{2}\right), 7.21(1 \mathrm{H}, \mathrm{s}, \mathrm{C}-6 \mathrm{Ar}-\mathrm{H}), 7.03\left(2 \mathrm{H}, \mathrm{d}, \mathrm{J}=7 \mathrm{~Hz}, \mathrm{C}-3^{\prime}, 5^{\prime} \mathrm{Ar}-\mathrm{H}\right)$, $7.46\left(2 \mathrm{H}, \mathrm{d}, \mathrm{J}=7 \mathrm{~Hz}, \mathrm{C}-2,6^{\prime} \mathrm{Ar}-\mathrm{H}\right), 7.48-7.89$ (7H,m, C-2", 3", 4",5",6",7",8" Ar-H); Anal. Calcd for: $\mathrm{C}_{20} \mathrm{H}_{15} \mathrm{FN}_{2} \mathrm{~S}: \mathrm{C}, 71.83 ; \mathrm{H}, 4.52 ; \mathrm{N}, 8.38$; Found: $\mathrm{C}$, 71.88; H, 4.59; N, 8.49.

6-(4-dimethylaminophenyl)4-(napthalen-5-yl)-2H-1,3-thiazin-2amine (P5) pale yellowish solid; Yield: $72 \%$; m.p. $129-131^{\circ} \mathrm{C}$; IR $(\mathrm{KBr}$ $\left.\mathrm{cm}^{-1}\right): 3310.58\left(\mathrm{NH}_{2}\right), 1640.72(\mathrm{C}=\mathrm{N}), 703(\mathrm{C}-\mathrm{S}), 1597.22(\mathrm{C}=\mathrm{C})$

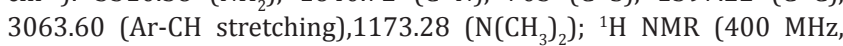
$\left.\mathrm{CDCl}_{3}, \mathrm{ppm}\right): 5.30\left(2 \mathrm{H}, \mathrm{s},-\mathrm{NH}_{2}\right), 3.10 .\left(6 \mathrm{H}, \mathrm{s},-\mathrm{N}\left(\mathrm{CH}_{3}\right)_{2}\right), 6.97(1 \mathrm{H}, \mathrm{s}, \mathrm{C}-6$ $\mathrm{Ar}-\mathrm{H}), 6.65$ (2H,d, J=7Hz, C-3',5' Ar-H), $7.30\left(2 \mathrm{H}, \mathrm{d}, \mathrm{J}=7 \mathrm{~Hz}, \mathrm{C}-2^{\prime}, 6^{\prime} \mathrm{Ar}-\mathrm{H}\right)$ 7.36-7.69 (7H,m, C-2",3",4",5",6",7",8" Ar-H); Anal. Calcd for: $\mathrm{C}_{22} \mathrm{H}_{21} \mathrm{~N}_{3} \mathrm{~S}: \mathrm{C}$, $73.50 ; \mathrm{H}, 5.89$; N, 11.69; Found: C, 73.61; H, 5.95; N, 11.73 .

6-(4-hydroxyphenyl)4-(napthalen-5-yl)-2H-1,3-thiazin-2-amine (P6) pale yellowish solid; Yield: $85 \%$; m.p. $155-157^{\circ} \mathrm{C}$; IR $\left(\mathrm{KBr}, \mathrm{cm}^{-1}\right)$ : $3418.13\left(\mathrm{NH}_{2}\right), 1642.85(\mathrm{C}=\mathrm{N}), 696(\mathrm{C}-\mathrm{S}), 1572.04(\mathrm{C}=\mathrm{C}), 3310.58$ $(\mathrm{OH}), 2952.23$ (Ar-CH stretching); ${ }^{1} \mathrm{H}$ NMR $\left(400 \mathrm{MHz}, \mathrm{CDCl}_{3}, \mathrm{ppm}\right)$ $4.22\left(2 \mathrm{H}, \mathrm{s},-\mathrm{NH}_{2}\right), 6.99(1 \mathrm{H}, \mathrm{s}, \mathrm{C}-6 \mathrm{Ar}-\mathrm{H}), 5.12(1 \mathrm{H}, \mathrm{s},-\mathrm{OH}), 6.79(2 \mathrm{H}, \mathrm{d}$ $\left.\mathrm{J}=7 \mathrm{~Hz}, \mathrm{C}-3^{\prime}, 5^{\prime} \mathrm{Ar}-\mathrm{H}\right), 7.31$ (2H,d, J=7Hz,C-2,6' Ar-H), 7.38-7.75 (7H,m, C-2",3",4",5",6",7",8" Ar-H); Anal. Calcd for: $\mathrm{C}_{20} \mathrm{H}_{16} \mathrm{~N}_{2} \mathrm{OS}$ : C, 72.26; H, 4.85; N, 8.43; Found: C, 54.59; H, 3.69; N, 8.47.

\section{Anticonvulsant activity}

According to neurological theory, epilepsy is a paroxysmal, self-limited cerebral dysrhythmia. It is accompanied by abnormal patterns on the electroencephalograph, and severe seizures may cause a loss of consciousness. It may or may not be associated with body movements or hyperactivity of the autonomic nervous system. All the experimental protocols and procedures described hereupon were prior approved by the Institutional Animal Ethics Committee. The method followed for activity is PTZ-induced Seizures [25-28]. Diazepam $(10 \mathrm{mg} / \mathrm{kg})$ and PTZ were dissolved in normal saline. The healthy albino rats (Wistar, 100-150 g, 5-6 weeks) were kept under standard laboratory conditions (room temperature: $23+28^{\circ} \mathrm{C}$; relative humidity: $60+5 \%$; illumination: $12 \mathrm{hrs}$ light/dark cycle) and had freely access to food pellets and fresh water except for the short time duration when animals were removed for pharmacological testing. All experiments were performed between 9.00 AM and 2.00 PM. The animals were divided into 14 groups of six animals each for two test drugs. Group 1 is treated as a negative control and injected subcutaneously with PTZ at dose of $85 \mathrm{mg} / \mathrm{kg}$ body weight. Group 2 serves as standard and treated with diazepam injected intraperitoneally at a dose of $10 \mathrm{mg} / \mathrm{kg}$ body weight. Groups 3-6 and 7-14 were treated with test compounds A1-A6 and P1-P6, respectively, at a dose of $100 \mathrm{mg} / \mathrm{kg}$ ip. Animals were pretreated with the test drug 30 minutes and diazepam 15 minutes before administration of PTZ $85 \mathrm{mg} / \mathrm{kg}$ subcutaneously. The onset of total duration as well as the frequency of clonic seizures was measured within a 30 minutes period and $\%$ mortality was measured, and the results are summarized in Table 1.

\section{RESULTS AND DISCUSSIONS}

\section{Chemistry}

Novel chalcones (A1-A6) were prepared by Claisen-Schmidt condensation reaction of 1 -acetyl naphthalene with different aromatic aldehydes in the presence of base. These synthesized chalcones are further utilized as synthons for preparing 1,3-thiazines (P1-P6). All the compounds are purified by column chromatography and characterized by IR and ${ }^{1} \mathrm{H}$ NMR spectral methods and elemental analysis. Construction of the chalcones is confirmed by characteristic carbonyl and olefinic IR absorption bands in between 1660 and $1670 / \mathrm{cm}$ and 1510 and $1520 / \mathrm{cm}$, whereas the bands in the IR

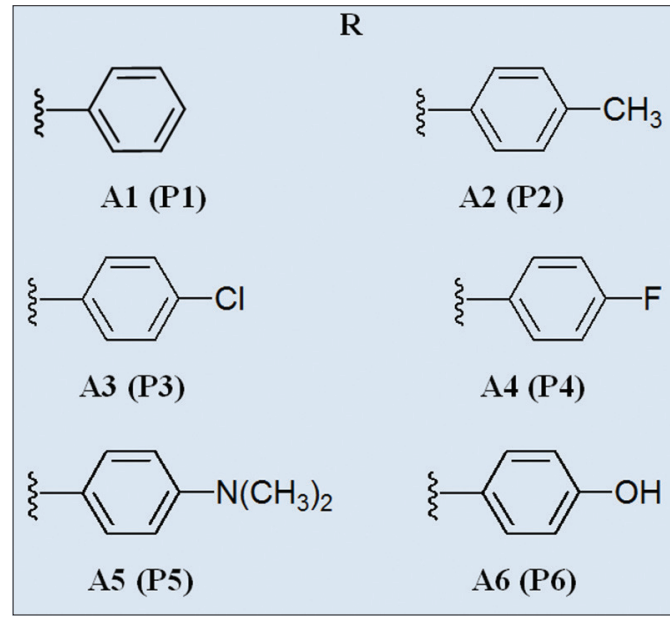

Fig. 3: Various substituted aromatic aldehydes

Table 1: Results of the anticonvulsant activity of chalcones (A1-A6) and 1,3-thiazines (P1-P6)

\begin{tabular}{lllll}
\hline Group & $\begin{array}{l}\text { Number } \\
\text { of animals } \\
\text { used }\end{array}$ & $\begin{array}{l}\text { Onset of } \\
\text { convulsions } \\
\text { (seconds) }\end{array}$ & $\begin{array}{l}\text { Number } \\
\text { of animals } \\
\text { died }\end{array}$ & $\begin{array}{l}\text { Percentage } \\
\text { mortality }\end{array}$ \\
\hline PTZ & 6 & $89 \pm 2.16$ & 6 & 100 \\
STD+PTZ & 6 & $0 \pm 0$ & 0 & 0 \\
PTZ+A1 & 6 & $126.8 \pm 1.85$ & 2 & 33.33 \\
PTZ+A2 & 6 & $116.5 \pm 0.61$ & 3 & 50 \\
PTZ+A3 & 6 & $131.2 \pm 1.83$ & 2 & 33.33 \\
PTZ+A4 & 6 & $142.3 \pm 2.27$ & 1 & 16.66 \\
PTZ+A5 & 6 & $120 \pm 0.93$ & 3 & 50 \\
PTZ+A6 & 6 & $116.2 \pm 0.79$ & 3 & 50 \\
PTZ+P1 & 6 & $143.5 \pm 1.25$ & 2 & 33.33 \\
PTZ+P2 & 6 & $138.5 \pm 1.25$ & 3 & 50 \\
PTZ+P3 & 6 & $151 \pm 1.52$ & 1 & 16.66 \\
PTZ+P4 & 6 & $155.2 \pm 1.42$ & 1 & 16.66 \\
PTZ+P5 & 6 & $144.3 \pm 0.88$ & 2 & 33.33 \\
PTZ+P6 & 6 & $138.5 \pm 0.76$ & 3 & 50 \\
\hline
\end{tabular}

Values are expressed as mean \pm SEM of each group $(n=6)$ and are significant when done One-way ANOVA with Tukey's post hoc test. ${ }^{* * *}$ p $<0.001$ when compared with disease control. PTZ: Pentylenetetrazole, SEM: Standard error of mean 


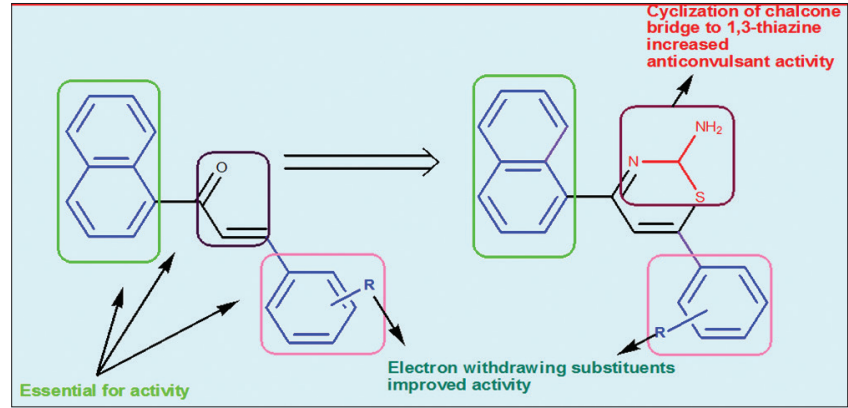

Fig. 4: Summary of the SAR features of chalcones and 1, 3-thiazines for anticonvulsant activity

spectrum of P1-P6 at $3310-3350 / \mathrm{cm}\left(-\mathrm{NH}_{2}\right), 1600-1650 / \mathrm{cm}(-\mathrm{C}=\mathrm{N}-$ ), and $680-715 / \mathrm{cm}$ (C-S), respectively, confirms the formation of thiazines. Two characteristic doublets at chemical shift values in between 7.5 and $7.65(\alpha-\mathrm{H})$ and 7.9 and $7.95(\beta-\mathrm{H})$ with coupling constant (J=17 HZ), respectively, in the proton NMR spectrum of chalcones and a diagnostic singlet at 6.90-7.25 (C-6 Ar- $\mathrm{H})$ in the spectrum of thiazines, respectively, further assisted in resolving the structures of the compounds. The composition of the compounds was confirmed by elemental analysis, and the results were also in close agreement with those of the calculated values.

\section{Anticonvulsant activity}

Chalcones and 1,3-thiazine derivatives were tested for their anticonvulsant activity by the following PTZ-induced clonic convulsions method and the results are summarized in Table 1. From the results, it can be clearly notified that both chalcones and 1,3-thiazines possessed anticonvulsant activity but less than the standard diazepam. The onset of convulsions was prolonged by 1,3-thiazines than chalcones which represented that cyclization of the enone system of chalcones to thiazine is more essential for activity. Both in chalcones and 1,3-thiazines, compounds A3, A4, P3, and P4 containing electron withdrawing halogen atoms on the phenyl ring were found to be more active. Phenyl substitution with electron-releasing substituents like methyl, dimethylamino and hydroxyl groups as seen in compounds $\mathrm{A} 2$, A5, A6, P2, P5, and P6 were less active than the unsubstituted A1 and P1.

Structure-activity relationships (Fig. 4) based on the results suggested that chalcone and 1,3-thiazine scaffolds linked with naphthyl and phenyl portions were essential for anticonvulsant activity and the phenyl portion when substituted with an electron withdrawing lipophilic halogen atoms like fluorine and chlorine substituents enhanced the activity.

\section{Statistical analysis}

The results were analyzed statistically using One-way ANOVA followed by Tukey's post hoc test and are represented as mean \pm standard error of mean. All groups are compared with disease control.

\section{CONCLUSION}

In our study, we have synthesized and characterized a series of chalcones as well as 1,3-thiazines. All the compounds exhibited some anticonvulsant activity with 1,3-thiazines being more potent than chalcones. Most potent of the 12 compounds is $\mathrm{P} 4$ with which the onset of convulsions at 155.2 seconds. Even its action is less compared to standard diazepam.

\section{ACKNOWLEDGMENTS}

We are grateful to the Management, Vignan Institute of Pharmaceutical Sciences, Hyderabad for providing necessary facilities for the outcome of this work.

\section{REFERENCES}

1. Lemke TL. Foye's Principles of Medicinal Chemistry. Philadelphia, PA: Lippincott Williams \& Wilkins; 2008. p. 1028-82.

2. Greene SA, Thurmon JC. Xylazine - A review of its pharmacology and use in veterinary medicine. J Vet Pharmacol Ther 1988;11:295-313.

3. Seeling A, Oelschläger H, Rothley D. Important pharmaceuticalchemical characteristics of the central muscle relaxant chlormezanone. Pharmazie 2000;55(4):293-6.

4. Rathore MM, Parhate VV, Rajput PR. Synthesis and antimicrobial activities of some bromo-substituted-1, 3-thiazines. Int J Res Pharm Biomed Sci 2013;4(1):9-62.

5. Ganorkar RS, Ganorkar RP, Parhate VV. Synthesis, characterisation and antibacterial activities of some new bromo/nitro 1,3-thiazenes. Rasayan J Chem 2013;6(1):65-7.

6. Haider F, Haider Z. Synthesis and antimicrobial screening of some 1,3-thiazines. J Chem Pharm Res 2012;4(4):2263-7.

7. Sayed HH, Shamroukh AH, Rashad AE. Synthesis and biological evaluation of some pyrimidine, pyrimido-[2,1-b]-1,3-thiazine and thiazolo-3,2-a-pyrimidine derivatives. Acta Pharm 2006;56(2):231-44.

8. Siddiqui IR, Singh PK. Novel one pot synthesis of 1,3-dithiins and 1,3-thiazines under microwave irradiation. Int $\mathrm{J}$ Chem 2007;46B(3):499-504.

9. Ali TE, El-Kazak AZ. Synthesis and antimicrobial activity of some new 1,3-thiazoles, 1,3,4-thiadiazoles, 1,2,4-triazoles and 1,3-thiazines incorporating acridine and 1,2,3,4-tetrahydroacridine moieties. Eur J Chem 2010;1(1):23.

10. Rathod SP, Charjan AP, Rajput PR. Synthesis and antibacterial activities of chloro-substituted-1, 3-thiazines. Rasayan J Chem 2010;3(2):363-7.

11. Kumar BK, Devi KV, Gupta PR, Kranthi G, Ramakrishna C, Sankaraiah P, et al. Synthesis and biological evaluation of different thiazine derivatives. J Pharm Res 2011;4(1):274-5.

12. Jupudi S. Screening of in-vitro anti-inflammatory activity of some newly synthesized 1,3-thiazine derivatives. Int J Res Pharm Chem 2013;3(2):213-20

13. Sanjeeva Reddy C, Nagara A. Synthesis and biological study of novel bis chalcones, bis-thiazines and bispyrimidines. J Iran Chem Soc 2008;5(2):262-7.

14. Kalirajan R, Sivakumar SU, Jubie S, Gowramma B, Suresh B. Synthesis and biological evaluation of some heterocyclic derivatives of chalcones. J Chem Tech Res 2009;1(1):27-34.

15. Udupi RH, Bhat AR, Jacob J. Synthesis and biological evaluation of some biphenyl ether and thiazine derivatives. Indian J Heterocycl Chem 2005; $15: 89$

16. Wang W, Zhao B, Xu C, Wu W. Synthesis and antitumor activity of the thiazoline and thiazine multithioether. Int J Organ Chem 2012;2(2):117-20.

17. Meric A, Ncesu Z, Hatipoglu I. Synthesis of some 3,4-disubstituted6,7-dihydro-imidazo[2,1-b][1,3]thiazole and 3,4-disubstituted-7,8dihydro- $6 \mathrm{H}$-imidazo[2,1-b][1,3]thiazine derivatives and evaluation of their cytotoxicities against F2408 and 5RP7 cells. Med Chem Res 2008;17(1):30-41

18. Beauchamp J, Benardeau A, Hilpert H, Wang H. 2-Aminodihydro [1,3] Thiazines as Bace 2 Inhibitors. For the Treatment of Diabetes. Patent Scope. World Intellectual Property Organization; 2011. p. 165.

19. Dabholkar VV, Parab SD. 1, 3-Thiazines and 1, 3-pyrimidines derivatives and their biological evaluation for anti-inflammatory, analgesic and ulcerogenic activity. Hetero Lett 2011;1(2):176-88.

20. Zawisza T, Matczak H, Kowalczyk-Bronisz SH, Jakóbiec T. Syntheses and pharmacological analysis of new derivatives of tetrahydro-[1,3]thiazine and 2-thiobarbituric acid. Arch Immunol Ther Exp (Warsz) 1981;29(2):235-48.

21. Foks H, Rudnicka W, Glowka M, Kaliszan R, Nasal A, Damasiewicz B, et al. Synthesis, structure and biological activity of 1,2,4-triazolo-1,3thiazine derivatives. Pharmazie 1992;47(10):770-3.

22. Jagodzinski TS, Wesolowska A, Jagodzinska E, Rump S. Synthesis and biological activity of certain novel derivatives of $1 \mathrm{H}$-pyrrolo[1,2-c] [1,3]thiazine. Acta Pol Pharm 2003;60(1):67-73

23. Yazdan SK, Sagar GV, Shaik AB. Biological and synthetic potentiality of chalcones. J Chem Pharm Res 2015;7(11):829-42.

24. Nagihan B, Bedia KK, Salih G, Feyza A. Synthesis and anticonvulsant activity of some 2-pyrazolines derived from chalcones. Arabian J Chem 2013;44:1-9.

25. Kulkarni SK. In: Handbook of Experimental Pharmacology. New Delhi, India: Vallabh Prakashan; 1993. p. 56.

26. Prakash CR, Raja S, Saravanan G. Synthesis, characterization and 
anticonvulsant activity of novel schiff base of isatin derivatives. Int J Pharm Pharm Sci 2010;2(4):177-81.

27. Rao T, Bhongade SL, More SM, Dongarwar AS, Shende VS, Pande VB. Effects of Lippia nodiflora extracts on motor coordination, exploratory behaviour pattern, locomotor activity, anxiety and convulsions on albino mice. Asian J Pharm Clin Res 2011;4(3):133-8.

28. Singh D, Maurya VB, Prajapati K, Kumar H, Niranjan PS, Jain SK Evaluation of anticonvulsant activity of the leaves ethanolic and aqueous extracts of Nyctanthes arbor-tristis Linn. Against seizures induced by PTZ and MES in mice. Int J Pharm Sci Res 2010;1(2):63-71 